IFN Working Paper No. 994, 2013

\title{
Trust, Welfare States and Income Equality: What Causes What?
}

\section{Andreas Bergh and Christian Bjørnskov}




\title{
Trust, Welfare States and Income Equality: \\ What Causes What?
}

\section{Andreas Bergh \& Christian Bjørnskov*}

December, 2013

\begin{abstract}
The cross-country correlation between social trust and income equality is well documented, but few studies examine the direction of causality. We show theoretically that by facilitating cooperation, trust may increase efficiency and lead to more equal outcomes, while the feedback from inequality to trust is ambiguous. Using a structural equations model estimated on a large country sample, we find that trust has a positive effect on both market and net income equality. Larger welfare states lead to higher net equality but neither net income equality nor welfare state size seems to have a causal effect on trust. We conclude that while trust facilitates welfare state policies that may reduce net inequality, this decrease in inequality does not increase trust.
\end{abstract}

Keywords: Social trust; Inequality, Welfare State

JEL: H10; D63; D69

\footnotetext{
* Bergh: The Research Institute for Industrial Economics (IFN), P.O. Box 55665, SE-102 15 Stockholm, Sweden, and Lund University, email: andreas.bergh@ifn.se. Bjørnskov: Aarhus University, Department of Economics and Business, Hermodsvej 22, DK-8230 Åbyhøj, Denmark, email: chbj@asb.dk. We thank Tim Reeskens, Patrick Sturgiss, Eric Uslaner and participants at the 2011 ECPR conference and a seminar at the IFN in Stockholm for commenting on an earlier version of the paper. Bergh thanks Vetenskapsrådet for their financial support. All remaining errors are naturally ours.
} 
The cross-country correlation between social trust and national income equality is well documented, but few studies examine the direction of causality. It is often assumed that inequality leads to lower trust (Uslaner 2002; Delhey and Newton 2005; Bjørnskov 2007, 2008), but the theoretical mechanisms involved are still subject to debate (as shown in overviews by Jordahl 2008 and Nannestad 2008).

A mechanism supporting a causal link from trust to equality is suggested by findings in Bergh and Bjørnskov (2011) and Bjørnskov and Svendsen (2013), which show that historical trust levels explain current welfare state size. If bigger welfare states increase income equality, there will be a link from trust to equality mediated by the welfare state. Moreover, if equality increases trust, positive feed-back dynamics may take place, such that equality increases trust, and trust facilitates the implementation of welfare state redistribution, further fostering equality. Such dynamics are even more likely if universal welfare state policies have a positive effect on trust, as suggested by Barr (2004) and also Kumlin and Rothstein (2005). On the other hand, if the crosscountry correlation between income equality and social trust is driven only by the fact that deeply rooted trust levels explain both trust today and the degree of welfare state redistribution, there is no feed-back dynamic from redistributive welfare state policies to trust.

The possible causal relations are illustrated in Figure 1, where full arrows show causal relations argued for in previous literature. This paper investigates the causality between trust and equality, and the potential role of welfare state policies as mediators of the causal associations. We do so by exploring two central questions, not dealt with before. First, do welfare states have an independent effect on income equality, or is the correlation between welfare state size and income equality spurious, in the sense that trust explains both welfare state size and income equality? Second, if welfare states do increase equality of income, does this further increase trust, suggesting a positive feedback dynamics? 
Figure 1: The correlations between welfare state size, social trust and income equality.

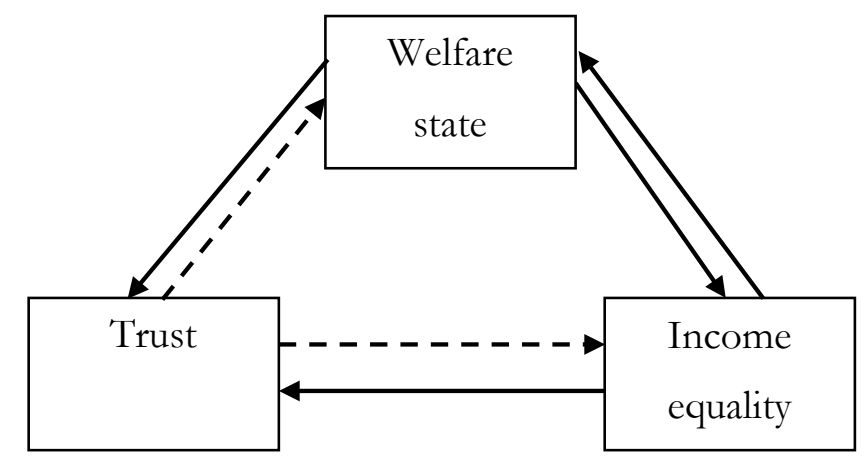

Departing from a standard cooperation game, we show that the overall type of cooperation facilitated by trust and trustworthiness will under plausible circumstances increase equality. We then estimate structural equations models that account for potential feedback effects between income equality and social trust. The results document a two-way causal relation between market (pre-redistribution) income inequality and social trust, but no feedback from net inequality to trust. Furthermore, the effect from trust to inequality is substantially stronger than the feedback. Our findings thus suggest that welfare state policies do increase equality in disposable income but do not increase trust.

We start the paper by discussing potential theoretical links between social trust and inequality. In section 3, we describe our empirical strategy to sort out the causal directions. Section 4 describes the data used in section 5 to estimate the relation. Section 6 discusses our findings and concludes. 


\section{LINKS BETWEEN SOCIAL TRUST AND INEQUALITY}

From a game-theoretic perspective, human interaction can be modeled as a number of repeated games of various types, as suggested by Binmore and Samuelson (1994). Some situations are best represented by zero-sum games, others by positive-sum games while problems such as rentseeking are best represented by negative-sum games. In some cases, interactions take place among people who know each other and are likely to meet again, in other situations people interact with strangers that they are unlikely to meet again. As noted by many authors, trust and trustworthiness are beneficial for society precisely because they help groups reach cooperative outcomes in positive-sum games. ${ }^{1}$ This holds for interactions in pairs, such as two people trading with each other, but also for large-N social dilemmas. As argued by Rothstein (2001), the welfare state can be seen as a large scale social dilemma, explaining why trust and trustworthiness are central for understanding the sustainability of the welfare state.

For example, there are potential efficiency gains from cooperation deriving from social insurance arrangements in the welfare state, as emphasized by for example Barr (1998). Trust and trustworthiness help sustain and protect these social insurance arrangements against free riding. ${ }^{2}$ From this perspective, it is not surprising that Bergh and Bjørnskov (2011) have demonstrated that more trusting populations tend to create and sustain larger welfare states. The welfare state can thus be seen as a mediator in the link from trust to equality.

At a broader level, Arrow (1972) noted that the vast majority of commercial transactions require an element of trust. Yet, when delivering homogenous goods in personal business transactions, social trust may not be relevant. Knack and Keefer (1997) define 'trust-sensitive transactions' as a class of transactions in which there is limited immediate monitorability. For

\footnotetext{
1 See, among many others, Knack and Keefer (1997), La Porta et al. (1997), Putnam (1993), Schelling (1960), Svendsen and Svendsen (2008), Sønderskov (2011).

2 Cf. Fong et al. (2006). Trust and trustworthiness are important not only for the formal social insurance systems of modern welfare states, but also for more the informal sharing arrangements. For example, Zhang et al. (2006) demonstrates how trust aids the implementation of community based health insurance in rural China.
} 
example, when trading heterogeneous goods, sellers will need to trust that the quality of the goods delivered by a number of often anonymous agents is up to the contracted standard.

Likewise, in the public sphere, Dahl (1971) stressed that people need to trust one another if they are to associate together in the achievement of those objectives which they cannot gain by their own individual action. For example, most bureaucratic transactions are anonymous and thus likely to be sensitive to trust differences, as are assessments of political actions and politicians (Bjørnskov 2010).

Summing up, there is consensus that cooperation resulting from trust and trustworthiness helps societies make efficient use of their resources. But as a result of previous research being focused on explaining cooperation, there is little research on the distributional consequences of trust-aided cooperation. A simple framework is provided below.

\section{Trust, cooperation and distribution}

Theoretical analyses of trust and cooperation typically use the prisoner's dilemma, described in Table 1. The classic example is Axelrod (1984). The outcome $\alpha$ is the reward for cooperation, $\beta$ is the temptation pay-off and $\gamma$ is the payoff when agents fail to cooperate. The pay-offs are normalized so that the outcome for cooperating when the other agent does not (the 'sucker payoff) is 0 . The game has proven extremely useful for analyzing the evolution of cooperation, but it says little about whether societies where agents cooperate more often will be more or less equal compared to less cooperating societies. In the standard prisoner's dilemma it is typically implicitly assumed that the gains from cooperation are shared equally, and the same holds when agents fail to cooperate. As a result, inequality among two agents in a prisoner's dilemma game arises only when one cooperates and the other defects. 
Table 1: Outcomes in a standard prisoner's dilemma game

\section{Cooperate Defect}

Cooperate $\quad \alpha, \alpha \quad 0, \beta$

Defect $\quad \beta, 0 \quad \gamma, \gamma$

In most real-life applications of positive-sum games, the gains from cooperation can, however, be distributed in many ways. Consider, for example, Arrow's (1972) example: a trade transaction. This is a positive-sum game because both the seller and the buyer are potentially better off if the transaction takes place, and the transaction is clearly facilitated by trust. But whenever the buyer's maximum willingness to pay exceeds the sellers' minimum acceptance price, there are several prices that would make them both better off. Thus, a successful transaction requires not only that the buyer and seller are sufficiently trusting and trustworthy, but also that they succeed in coordinating on the distribution of the surplus.

As a consequence, when the purpose is to analyze distributional aspects, positive-sum games are better illustrated graphically. An example is provided in Figure 2, where point 1 is the initial allocation, which will remain the outcome should both agents defect. Point 2 may be the outcome when the game is sequential, agent B initially trusts A completely, only to find that A defects and leaves B worse off compared to the initial allocation. ${ }^{3}$ Point 3 is the outcome when agents share the gains from cooperation equally, as indicated by the dotted line passing through points 1 and 3 .

3 In experimental research this possibility is often analyzed using the trust-game introduced by Berg, et al. (1995) where the agents are thought of as an investor and a trustee. 
Figure 2. A positive-sum game illustrated

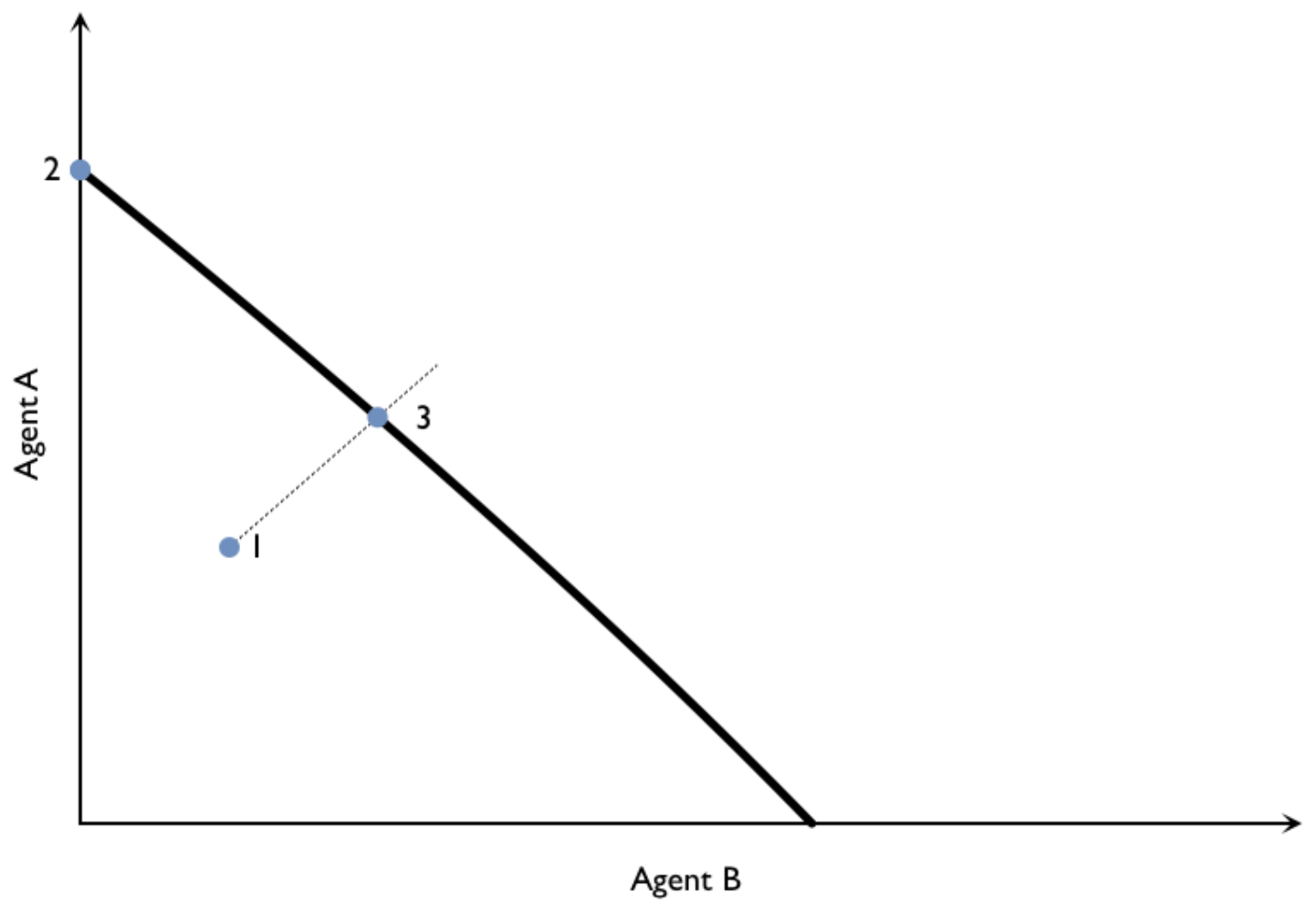

In real-life situations where agents are not constrained to choosing among fixed outcomes, but must actually agree on the distribution of the surplus, the norm of equal division is salient. It can easily be shown that whenever there is some initial inequality between agents A and B, sharing the gains from cooperation equally is a sufficient (but not necessary) condition for equality to increase as a result of the successful cooperation.

To see this, denote the initial allocation by $\left(\gamma_{A}, \gamma_{B}\right)$ and the outcome when agents cooperate by $\left(\alpha_{A}, \alpha_{B}\right)$. With some imagination, the initial allocation $\frac{\gamma_{A}}{\gamma_{B}}$ can be interpreted as the Hobbesian state of nature, where agents will end up should they fail to cooperate. Unless agents are identical, $\gamma_{\mathrm{A}}=\gamma_{\mathrm{B}}$ is unlikely. ${ }^{4}$ Inequality can be analyzed by comparing the ratio $\frac{\alpha_{A}}{\alpha_{B}}$ to $\frac{\gamma_{A}}{\gamma_{B}}$, allowing us to define equalizing cooperation as follows:

\footnotetext{
4 At least two simple assumptions seem more appropriate. One is that in the absence of cooperation resources are distributed in proportion to some individual ability that differs between agent 1 and agent 2. In a primitive society, this ability may be physical strength, as in the "jungle equilibrium" analyzed by Piccione and Rubinstein (2007). A second possibility is that, in the absence of cooperation, a conflict arises where the stronger agent takes all resources, leaving the other one with nothing.
} 
Definition: Cooperation is equalizing if and only if $\frac{\max \left(\alpha_{A}, \alpha_{B}\right)}{\min \left(\alpha_{A}, \alpha_{B}\right)}<\frac{\max \left(\gamma_{A}, \gamma_{B}\right)}{\min \left(\gamma_{A}, \gamma_{B}\right)}$.

Equalizing cooperation entails the players sharing the gains from cooperation such that the final allocation is more equal than the initial allocation. If the gains from cooperation are shared equally, cooperation is always equalizing if there is at least some inequality in the initial allocation:

Proposition 1: When $\frac{\gamma_{A}}{\gamma_{B}} \neq 1$, cooperation is equalizing if the gains from cooperation are shared equally.

Proof: Let the gains from cooperation be $g>0$. The result follows because $\frac{\max \left(\gamma_{A}+\frac{g}{2}, \gamma_{B}+\frac{g}{2}\right)}{\min \left(\gamma_{B}+\frac{g}{2}, \gamma_{B}+\frac{g}{2}\right)}<\frac{\max \left(\gamma_{A}, \gamma_{B}\right)}{\min \left(\gamma_{B}, \gamma_{B}\right)}$.

In political philosophy there are numerous accounts of how the gains from cooperation should be shared, including the maxi-min solution attributed to Rawls (1971), the utilitarian solution (Harsanyi 1955), the Nash bargaining solution (Nash 1950) and the Kalaia-Smorodinsky (1975) bargaining solution advocated by Gauthier (1987). When the utility possibility set is symmetric and convex, these different approaches lead to the same outcome: sharing the gains from cooperation equally between agents (Roemer 1996). Sharing the gains from cooperation equally can thus be understood as a focal point of distributive justice. ${ }^{5}$ Discussing the evidence of a positive relationship between market exchange and fair-minded, cooperative behavior, Ensminger (2004) noted that a simple fairness norm (such as equal division) may help people coordinate with other anonymous individuals on the market (cf. Young 1993). Experimental research suggests that cooperation is indeed often equalizing, and that the gains are often shared equality. For example, Hennig-Schmidt (2002) documents bargaining discussions in experimental settings similar to the one shown in Figure 2, and finds that two points are repeatedly used and

\footnotetext{
${ }^{5}$ The focal property of equal division is widely known, as discussed for example by Binmore (1994) and Skyrms (1996).
} 
described by the subjects as fair: the allocation that equalizes outcomes and the allocation that shares the gains from cooperation equally. ${ }^{6}$ Similarly, Ciriolo (2007) re-analyzes results from experimental trust games that have been interpreted as trust and reciprocity to show that agents often simply share the gains from participating in the experiment equally.

So far, we have considered a game between two agents and examined the distribution by comparing the distribution between the interacting agents in the case of mutual defection to the cooperative outcome. A number of extensions must be made before we can infer anything about how trust and cooperation affect the income distribution in society from the model.

First of all, the model described has only two agents, while many real-life strategic interactions involve more than two agents. The result in proposition 1, however, also applies to games with many players: if there are $N$ players, and the gains from cooperation $g$ are distributed equally, initial inequality will decrease as $g / N$ is added to all payoffs (unless initial inequality is 0 and nothing will change).

Second, the effect of cooperation on distribution cannot be analyzed only by looking at those agents who successfully cooperate. Equalizing cooperation between two or more agents may still increase the income difference between those who successfully cooperate with each other and those who do not. Furthermore, even if mutual cooperation entails higher equality than mutual defection, the effect of cooperation in society on equality will depend on the matching procedure: When cooperation is present but not universal, cooperators risk being paired with defectors, typically assumed to result in a very unequal payoff distribution. ${ }^{7}$

\footnotetext{
6 It should be noted that in the experimental literature, there is typically no choice of effort. While there are several suggestions that gains should be shared in proportion to effort among philosophers, the situation becomes difficult to control when effort is not observable. In the present context, it should however be noted that the utility possibility frontier is drawn given optimal effort responses: if A takes everything, B will probably not exert any effort, and $A$ is left with what she can produce on her own.

7 If some mechanism (such as reputation or signaling) implies that cooperators are able to identify each other and avoid interacting with defectors, the impact of defections on inequality will be smaller.
} 
In all, the arguments above point to an inverse- $\mathrm{U}$ relationship between the degree of cooperation and inequality in society similar to the original Kuznets curve. ${ }^{8}$ From a state of universal defection, equalizing cooperation among a few will lead to smaller relative differences among those who cooperate, but to higher inequality in society as a whole. In addition, inequality will increase as some cooperators end up being defected upon. As the degree of cooperation increases, inequality will start falling and eventually fall below the level in a society with no cooperation, as shown in Figure 3.

Figure 3. Social inequality and the share of cooperation

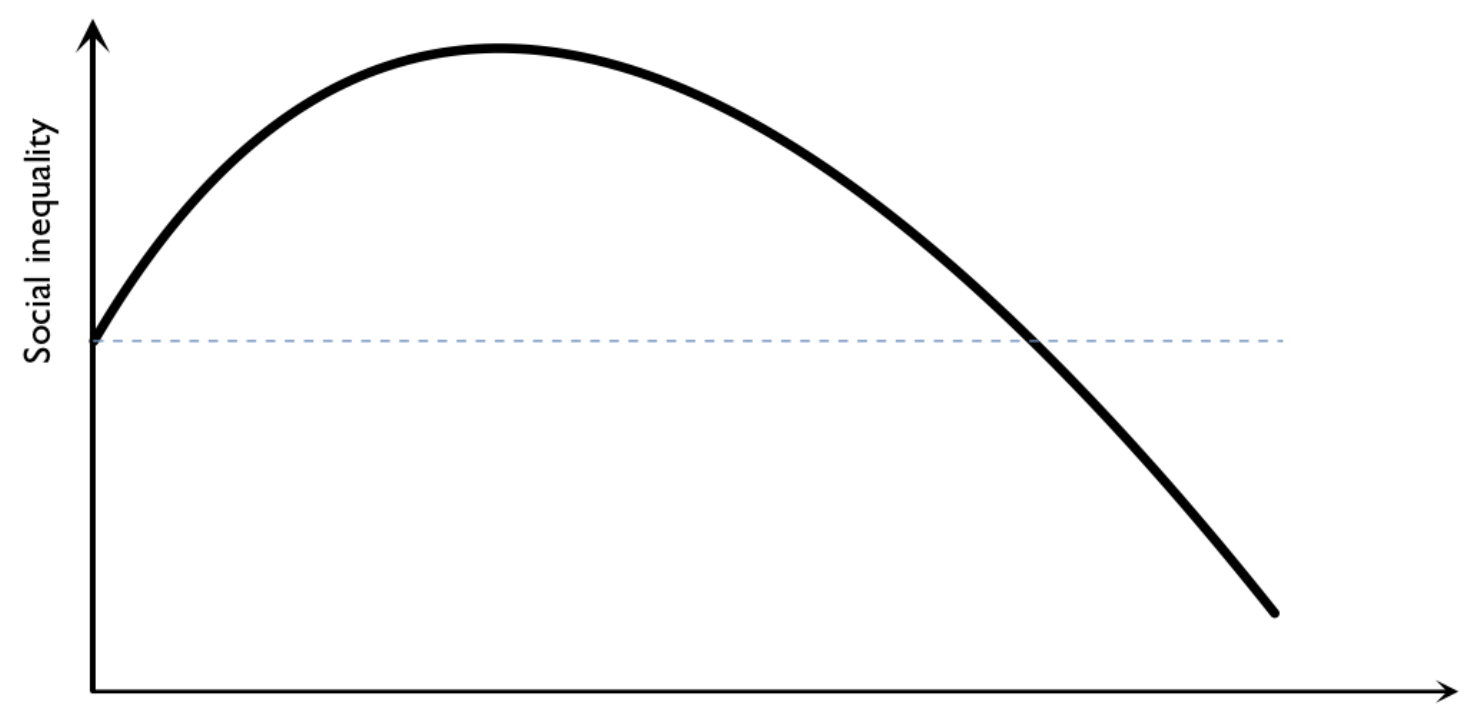

Share of cooperation

8 Kuznets (1955). 


\section{Feedbacks from equality to trust?}

Given the relationship between cooperation and inequality shown in Figure 3, it is hard for agents to infer much about the trustworthiness of others from the degree of inequality. An agent who sees inequality increase because a trusting individual is being defected upon is likely to become less trusting. Seeing inequality increase because several trustworthy individuals successfully cooperate with each other more likely has the opposite effect. ${ }^{9}$

Recent experimental evidence supports the complexity of the inequality-trust relationship. Greiner et al. (2912) find that trust is initially higher but decreases faster when trust games start with equal endowments. In a treatment with unequal endowments, trust is initially lower but more robust over time. Brülhart and Usunier (2012) find no effect on trust when making the trustee poorer than the first mover. Anderson et al. (2006) find only small and non-systematic effects of inequality in initial endowments on trusting behavior, while Sadrieh and Verbon (2006) find no systematic effect of inequality on cooperation in a public good game. To sum up, Greiner et al. (2012:355) seem right in concluding that "both the level and the (exogenous or endogenous) source of inequality matters for the dynamics of trust".

A key question is if the equality created by the welfare state is likely to feed back onto trust. Despite the seeming consensus in the literature, a theoretically informed answer to this question must remain ambiguous. Kumlin and Rothstein (2005) propose an impartiality argument according to which the impartiality of universal welfare states will lead people to infer that most people can be trusted. On the other hand, larger and more universal welfare states provide more opportunities for free-riding on publicly financed goods and benefits, and people may believe that such temptations make us less trustworthy. ${ }^{10}$ For both these mechanisms, the key factor is the size and structure of the welfare state.

9 To fully explore these mechanisms, the matching mechanism must be modeled. The more likely a cooperator is to meet another cooperator, the more likely it is that increasing incomes are the result of mutual cooperation.

${ }^{10}$ See Buchanan (1975), Coate (1995) and Lindbeck (1995). 
Another possible mechanism is that low income earners may have more to gain from defection when inequality is high, as noted by Gustavsson and Jordahl (2008). As a result, high income earners may worry more about crime and social unrest when inequality is high. ${ }^{11}$

Finally, we have already noted that in highly trusting societies, inequality will increase as a result of non-trustworthiness in private interactions, when people take advantage of others' trust. ${ }^{12}$ In a welfare state, such opportunistic behavior will primarily affect the market income distribution, as welfare state policies mitigate the effect on inequality of net income. Thus, at least for the net income distribution, welfare state redistribution may distort the signal value on trustworthiness contained in the income distribution, making it harder to distinguish defectors from the trusting and trustworthy.

Hypotheses regarding trust, inequality and welfare state size

Based on the reasoning above, we now formulate the following hypotheses for empirical testing:

H1: Countries with higher trust levels will have bigger welfare states and lower net income inequality.

H2: Countries with higher trust levels will have lower market inequality as well as net inequality also when controlling for welfare state size.

Importantly, these two hypotheses do not exclude the possibility of a feedback from inequality to trust. On the contrary, the links reviewed suggest that

H3: Market inequality decreases trust, given a sufficient signal, while for net inequality theoretical expectations are ambiguous.

11 This theory predicts that social trust would correlate negatively with wealth within a country. It is worth noting, however, that in the vast majority of countries, high income earners tend to be relatively more trusting. 12 For example, by billing large companies small amounts of money for services they have never used and hoping that these bills will be paid automatically by trusting accountants. 


\section{IDENTIFYING CAUSALITY USING A STRUCTURAL EQUATIONS MODEL}

To test our hypotheses as formulated above, a natural choice is to employ a structural equations model, where the long-run equilibrium determinants of trust and inequality are estimated simultaneously, allowing for a varying degree of endogeneity. Figure 4 outlines the overall model that we estimate by equations 1) and 2).

Figure 4. The empirical system

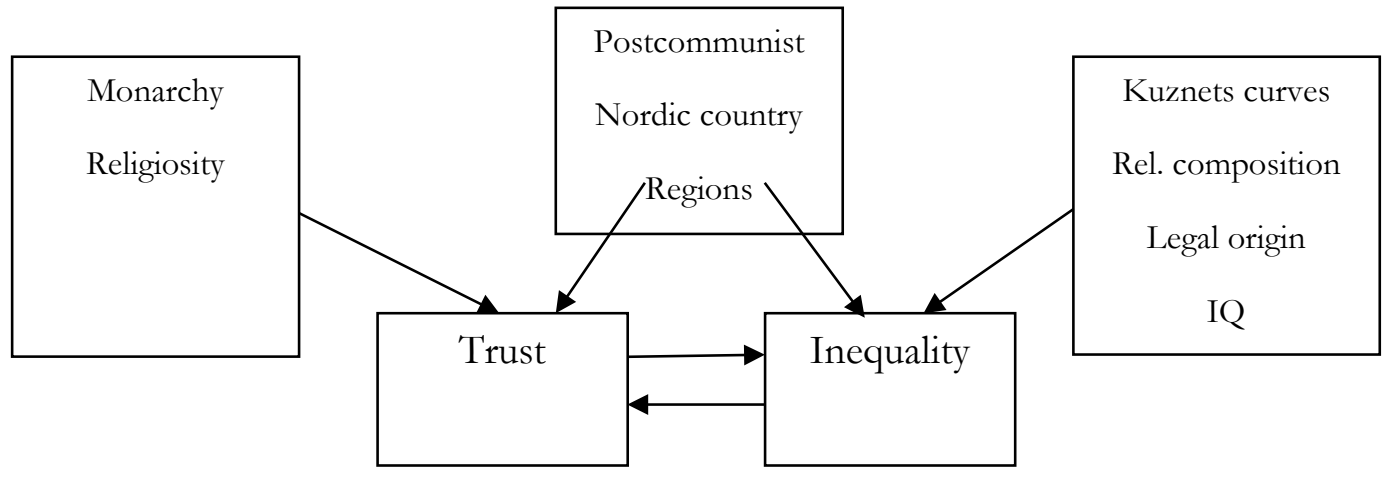

$$
\begin{aligned}
& \mathrm{TR}=\alpha_{1}+\beta_{1} \mathrm{X}+\gamma_{1} \mathrm{Y}+\lambda_{1} \mathrm{I}+\varepsilon_{1} \\
& \mathrm{I}=\alpha_{2}+\beta_{2} \mathrm{X}+\gamma_{2} \mathrm{Z}+\lambda_{2} \mathrm{TR}+\varepsilon_{2}
\end{aligned}
$$

The validity of our approach rests on the assumption that there are vectors of variables $(Y$ and $Z)$ specific to either part of the system that are properly exogenous, i.e. factors that affect trust (TR), but not inequality $(I)$, and vice versa. It also necessarily rests on sufficiently strong identification of both parts. As such, the structural approach is in principle similar to two linked instrumental variables estimates with the specific variables in $Y$ and $Z$ as instruments. It is nevertheless more flexible than standard instrumental estimators by allowing explicitly for two-way causality and covariance of the error terms.

To infer exogenous variation in inequality ( $Z$-variables), we use a standard Kuznets curve (GDP per capita and its squared term), a political Kuznets curve (the degree of democracy and its squared term), a set of dummy variables capturing variations in religious affiliation, and a control 
for common law countries (i.e., countries with some form of British heritage). Finally, we include IQ scores as proxies for educational quality to control for inequality arising from skills-based technological progress. ${ }^{13}$

Similarly, exogenous variation in trust is inferred using a dummy variable for monarchies and a measure of religiosity ( $Y$-variables). We include religiosity following Berggren and Bjørnskov (2011) while monarchy is included based on previous research in Bjørnskov (2007, 2010) and Robbins (2012). Variables common to both inequality and trust, i.e. our X-vector, are two dummies for post-communist countries that are both less trusting and more equal, and for Nordic countries, that have large welfare states, and are substantially more trusting, all other things being equal. We include the Nordic dummy as most recent studies find that trust levels in these countries are substantially higher than in the rest of the world, regardless of whether one controls for inequality and the size of the welfare state. Since the Nordic countries also have particularly low levels of net income inequality, not taking these differences into account would bias all estimates.

The system of equations 1) and 2) is estimated simultaneously with the predicted values for trust as an independent variable when explaining inequality, and predicted inequality values to explain trust. This allows us to identify either a two-way causality, or a one-way causality in either direction. ${ }^{14}$ However, while this type of modeling may be more flexible than standard two-stage least squares, it obviously rests to an equal extent on having variables specific to one equation that are exogenous to the residual of the other equation. We have therefore used separate twostage least squares regressions to test the exclusion restrictions of the structural system. We find no evidence of overidentification problems with the excluded variables in either part of the system. As we note that the goodness-of-fit statistics also reveal that both parts are properly predicted and that specific variables hold sufficient predictive power, we are unlikely to suffer

\footnotetext{
${ }_{13}^{13}$ See Johnson (1997) and Lemieux (2006).

14 Note that the causal relation from trust to welfare state size has been demonstrated in previous studies (Bergh and Bjørnskov 2011, Bjørnskov and Svendsen 2013). We therefore do not model welfare state size explicitly, but only treat it as a potentially moderating variable in the following.
} 
from underidentification problems. Sargan-Hansen tests also are likely to pick up significant collinearity between specific variables and inequality, which implies that our specification does not prevent us from identifying particular causal effects. These statistics are consistently insignificant with $\mathrm{p}$-values above $.5 .^{15}$

A potential problem might be that a substantial part of the identification occurs as a difference between rich, middle-income and very poor countries, for which redistributive policies are not a real option. This problem would make measures of net and market inequality almost identical in part of our sample, which would prevent proper identification of the likely effects of redistributive policy that is captured through the difference between net and market measures. We therefore report all main results in a reduced sample covering 89 countries in which we only keep countries with a GDP per capita above 2000 USD while results in the full 104-country sample are reported in an appendix.

\section{DATA}

Measuring income inequality and social trust both represent potential problems. Inequality in particular is measured in a variety of ways, and estimated from surveys and other information of very varying quality and coverage, as collected for example in the Deininger and Squire database. ${ }^{16}$ To be properly comparable, the large variety of measures therefore needs to be standardized.

We use data from the standardized world income inequality database by Solt, which categorizes income inequality calculated from different types of income measures into 21 categories. ${ }^{17}$ He thereafter estimates all differences between these inequality measures, thereby obtaining a large set of ratios. These ratios are then used to generate predictions in other categories of inequality, generated through multilevel modeling. The final measures of market and

\footnotetext{
15 The full 2SLS estimates are available from the authors upon request.

${ }^{16}$ Deininger and Squire (1996).

17 Solt (2009).
} 
net income inequality therefore not only take advantage of all available information, but also of the quality of that information. The result is a large database of Ginis that are as comparable as practically possible, given the information available from each country and each year.

This provides us with a large dataset from which we take the average of all available measures of net and market income inequality, respectively, between 2002 and $2006 .{ }^{18}$ Our dataset with full information on all main variables includes 104 countries, spanning the globe and all levels of economic and political development.

In order to test the associations between inequality and social trust, we use data from a number of sources. First, we follow the literature by employing what has become the standard measure of social trust over the last decade: the percent of a population that answers yes to the question "In general, do you think most people can be trusted?" In our full sample of 104 countries, this measure varies between a low of $3.4 \%$ in Cape Verde and a high of $68.1 \%$ in Denmark; the other Scandinavian welfare states, Norway and Sweden, have only marginally lower trust scores. The full sample average is $25.3 \%$, putting into perspective how high the Nordic trust scores are. We draw these data from the five waves of the 2010 World Values Survey, combined with data from the AfroBarometer, Asian Barometer, East Asian Barometer, LatinoBarometro, and the Arab Barometer. ${ }^{19}$

Despite criticism, the trust measure in general does well in various validity tests and is remarkably stable over time. ${ }^{20}$ Although the question may seem unclear and imprecise, it correlates strongly with return rates in wallet-drop experiments, which capture the honesty of people in a situation that is unobservable to formal institutions (see Knack and Keefer 1997). Indepth interviews and extended surveys show that this simple question measures respondents'

\footnotetext{
${ }^{18}$ Net inequality is here used for inequality post taxes and transfers, and market inequality refers to gross inequality (pre taxes and transfers).

19 The trust dataset is thus identical to that used in Berggren and Bjørnskov (2011).

${ }^{20}$ The examples of obviously non-stationary trust scores since the early 1980 s include the much-discussed declines in the USA and the UK (though this drop only occurs in the World Values Survey but not in the contemporaneous British Social Attitudes Survey), and also positive trends in Denmark and Uruguay. Trust is trendless in most other countries (Bjørnskov 2007, Uslaner 2008). We therefore use the average of all available observations.
} 
trust in strangers, while their trust in individuals they know or have specific information on is a quite different and approximately orthogonal concept, as discussed by Bjørnskov (2007), Naef and Schupp (2009) and Uslaner (2002). Nannestad (2008:419) also emphasizes that "respondents do not in general seem to find the generalized trust question difficult," as only roughly five percent of respondents in developed countries do not or cannot respond to the question. Recent evidence furthermore indicates that trust questions do well in explaining observed behavior in experiments. Actual trusting behavior in ultimatum games, trust games and public goods games correlates with respondents' answers to the trust question, although perhaps primarily in situations in which the stakes are of economic significance. ${ }^{21}$ Yet, one exception is Holm and Danielsson's (2005) of trust in Sweden and Tanzania, which suggests that the trust question may be a rather noisy measure in the least developed countries.

As for control variables, we keep the trust specification rather minimalistic in line with Nannestad (2008) who stresses that only a few variables have proved to be robustly associated with trust. We predict social trust by dummies for post-communist countries, constitutional monarchies and the Nordic countries, and the Gallup (2009) measure of the salience and intensity of religiosity, following recent work in Berggren and Bjørnskov (2011). To this simple specification, we add one of the two measures of inequality.

As determinants of inequality, we first of all include variables controlling for two types of Kuznets curves. We include the logarithm to GDP per capita, measured in PPP adjusted US dollars, as well as it squared term. ${ }^{22}$ This effectively controls for the traditional Kuznets curve which states that inequality is increasing in economic development at low levels of development, due to sectorally unbalanced growth, while it will be decreasing in development from some level, as other sectors and political redistribution outweighs the initial effects. ${ }^{23}$ Second, we also add the more recent explanation of a political Kuznets curve (cf., Chong, 2004). The rationale is that with

\footnotetext{
21 Sapienza et al. (2007), Cox et al. (2009).

22 GDP data are from Heston et al. (2009).

23 Kuznets (1955).
} 
increasing democratic influence, larger groups in society will become politically influential and thus be able to tweak redistributive policies in their favor. At some point, the electorate and thus redistributive politics becomes sufficiently representative of the entire population that further democratic development will cause a more even distribution of incomes. As such, the subsequent inclusion of poorer groups of voters in politics gives rise to a non-linear version of Director's Law (Stigler, 1970).

A number of other potential explanations need inclusion. We add further variables capturing common law systems (i.e., Anglo-Saxon cultural backgrounds), religious affiliations, intelligence quotients that proxy for the quality of education and hence skill-bias explanations of income inequality, and dummies for postcommunist and Nordic countries that for obvious reasons may be different. We also include a set of regional dummies capturing differences between Asia, Latin America and the Caribbean, North Africa and the Middle East, and SubSaharan Africa; the comparison group is thus countries belonging to the Western political Hemisphere.

Finally, we consider welfare state characteristics as potential moderators of the trustinequality association. To capture the relevant factors, we employ three variables in subsequent analysis. Government final consumption expenditures (percent of GDP) measure the provision of publicly provided goods and services (Heston et al., 2009); government full expenditures capture the full activities of the government sector including both public consumption and transfers (CIA 2010), i.e. all redistributive effort; and transfers and subsidies (percent of GDP) from Gwartney et al. (2010) specifically capture directly redistributive policy such as social transfers.

In a set of robustness tests, we include further control variables informed by the literature: ethnic diversity, measured as one minus the Herfindahl-Hirschman index of ethnicity (Alesina et al., 2003), the absence of corruption from Transparency International (2010), urban population (percent of total) and population density from the World Bank (2010), coup intensity (coups per 
decade, from Marshall and Marshall 2009), and trade volumes as percent of GDP from Heston et al. (2009).

\section{RESULTS}

As a first impression, Figures 5 and 6 provide scatter plots of the inequality-trust association, measured by market and net inequality, respectively. Both figures depict the clear negative association identified in the literature, although they also exhibit one particular feature: while the Nordic welfare states have some of the lowest levels of net inequality, market inequality, i.e. pretransfer, pre-tax inequality, is not particularly low in these countries. It is this regularity that has caused some of the special attention to these countries and the welfare state in particular. Yet, the record Nordic trust levels could be caused by the obvious redistribution or they might reflect that trust allows a Nordic level of income redistribution. ${ }^{24}$

${ }^{24}$ cf. Nannestad (2008). 
Figure 5. Trust and net income inequality

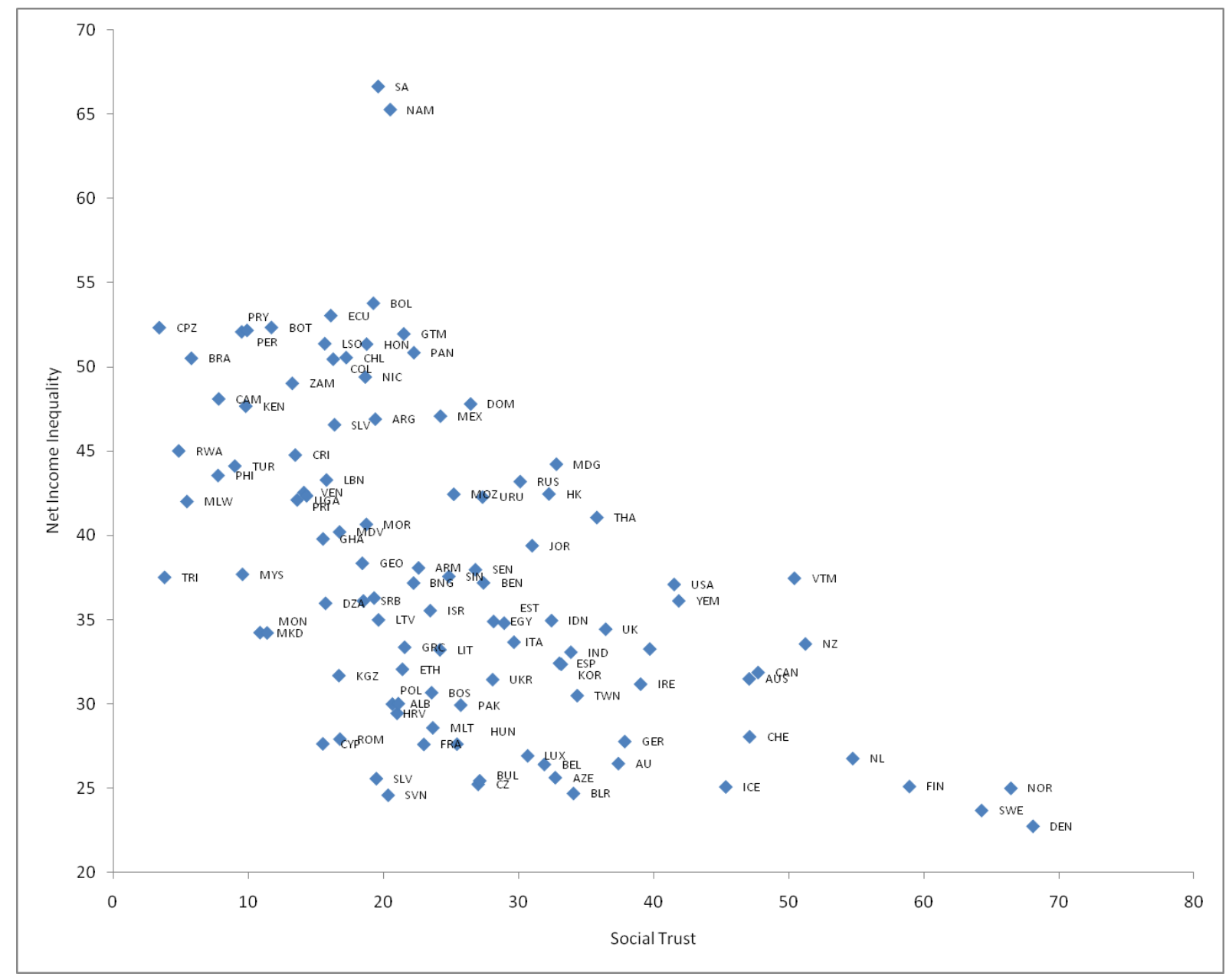


Figure 6. Trust and market income inequality

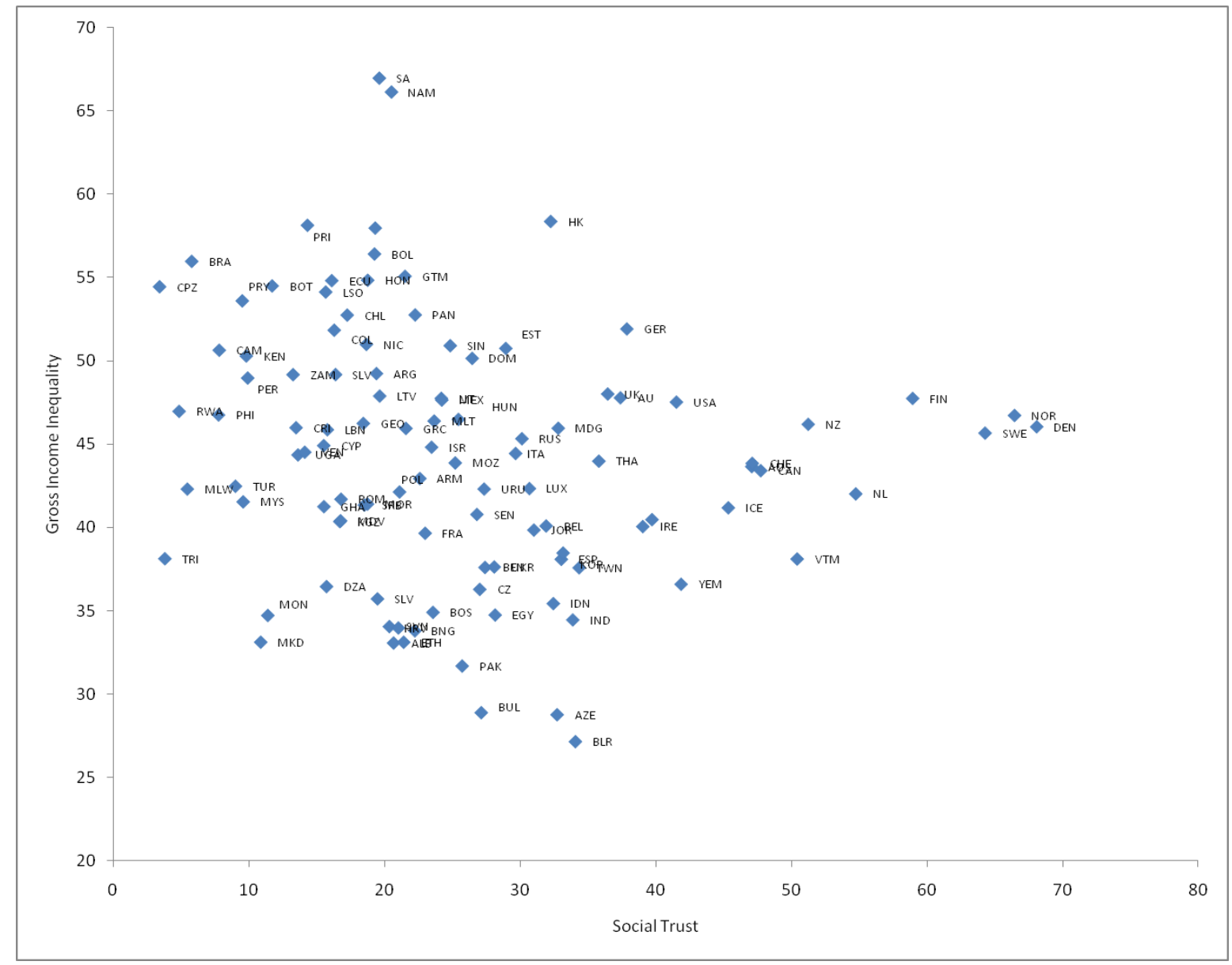

Table 2 presents the formal results of estimating our simple, two-way system between income inequality and social trust. Throughout the tables, we use net income inequality in columns 1-2 and market inequality in columns 3-4. Odd-numbered columns report the results of the trust specification while even-numbered columns report the inequality results. We chose for two reasons to report the results for the restricted sample of 89 countries. First, for the group of countries with a GDP per capita below 2000 USD, there is very little political redistribution and the difference between net and market measures is thus likely to be due primarily to noise. Second, although the trust measure works very well in most cases, there are reasons to believe that the measure itself as well as the surveys it derives from is questionable for the very poorest countries (cf. Holm and Danielson, 2005). 
Table 2. Main results.

\begin{tabular}{|c|c|c|c|c|}
\hline & $\begin{array}{c}\text { Trust } \\
1\end{array}$ & $\begin{array}{c}\text { Inequality } \\
2\end{array}$ & $\begin{array}{c}\text { Trust } \\
3\end{array}$ & $\begin{array}{c}\text { Inequality } \\
4\end{array}$ \\
\hline Monarchy & $\begin{array}{c}6.627 * * * \\
(2.422)\end{array}$ & & $\begin{array}{c}6.321 * * * \\
(2.388)\end{array}$ & \\
\hline Religiosity & $\begin{array}{c}-20.422^{* * *} \\
(4.427)\end{array}$ & & $\begin{array}{c}-21.308^{* * *} \\
(4.265)\end{array}$ & \\
\hline Postcommunist & $\begin{array}{c}-9.162^{* * *} \\
(2.281)\end{array}$ & $\begin{array}{c}-7.556^{* * *} \\
(1.811)\end{array}$ & $\begin{array}{c}-11.019^{* * *} \\
(2.414)\end{array}$ & $\begin{array}{c}-8.658^{* * *} \\
(2.513)\end{array}$ \\
\hline Nordic country & $\begin{array}{c}18.447^{* * * *} \\
(3.746)\end{array}$ & $\begin{array}{c}-5.344^{*} \\
(2.826)\end{array}$ & $\begin{array}{c}19.186^{* * * *} \\
(3.625)\end{array}$ & $\begin{array}{c}.583 \\
(3.926)\end{array}$ \\
\hline Log GDP per capita & & $\begin{array}{c}-7.126 \\
(13.384)\end{array}$ & & $\begin{array}{l}-28.898 \\
(18.503)\end{array}$ \\
\hline Log GDP squared & & $\begin{array}{r}.160 \\
(.752)\end{array}$ & & $\begin{array}{c}1.588 \\
(1.039)\end{array}$ \\
\hline Democracy & & $\begin{array}{l}.426 * * * \\
(.138)\end{array}$ & & $\begin{array}{l}.409^{* *} \\
(.191)\end{array}$ \\
\hline Democracy squared & & $\begin{array}{c}-.098 * * * \\
(.022)\end{array}$ & & $\begin{array}{c}-.077^{* *} \\
(.030)\end{array}$ \\
\hline Common law & & $\begin{array}{c}.284 \\
(1.289)\end{array}$ & & $\begin{array}{l}-2.657 \\
(1.783)\end{array}$ \\
\hline Orthodox & & $\begin{array}{c}-.048^{* *} \\
(.021)\end{array}$ & & $\begin{array}{c}-.090 * * * \\
(.029)\end{array}$ \\
\hline Catholic & & $\begin{array}{c}-.059 * * * \\
(.019)\end{array}$ & & $\begin{array}{c}-.080 * * * \\
(.026)\end{array}$ \\
\hline Protestant & & $\begin{array}{l}-.009 \\
(.032)\end{array}$ & & $\begin{array}{c}.002 \\
(.044)\end{array}$ \\
\hline Muslim & & $\begin{array}{c}-.119^{* * *} \\
(.024)\end{array}$ & & $\begin{array}{c}-.155^{* * *} \\
(.033)\end{array}$ \\
\hline Eastern religion & & $\begin{array}{l}-.026 \\
(.028)\end{array}$ & & $\begin{array}{l}-.076^{*} \\
(.039)\end{array}$ \\
\hline Intelligence quotient & & $\begin{array}{l}.201 * \\
(.108)\end{array}$ & & $\begin{array}{c}.073 \\
(.149)\end{array}$ \\
\hline Net inequality & $\begin{array}{l}-.113 \\
(.174)\end{array}$ & & & \\
\hline Market inequality & & & $\begin{array}{c}-.285^{* *} \\
(.132)\end{array}$ & \\
\hline Social trust & & $\begin{array}{c}-.136 * * * \\
(.052)\end{array}$ & & $\begin{array}{c}-.252 * * * \\
(.072)\end{array}$ \\
\hline Regional dummies & Yes & Yes & Yes & Yes \\
\hline Observations & 89 & 89 & 89 & 89 \\
\hline R squared & .736 & .889 & .733 & .658 \\
\hline Chi squared & 250.08 & 721.61 & 258.32 & 185.02 \\
\hline RMSE & 6.944 & 3.206 & 6.980 & 4.532 \\
\hline
\end{tabular}

Note: ${ }^{* *}(* *)[*]$ denote significance at $\mathrm{p}<.01(\mathrm{p}<.05)[\mathrm{p}<.10]$; regional dummies control for Asia, Latin America and the Caribbean, North Africa and the Middle East, and Sub-Saharan Africa. The results only include countries with a GDP per capita above 2000 USD in American 2005 dollars.

The estimates of trust in general provide support for the simple specification. In columns 1 and 3 , the specification explains about $73 \%$ of the variation, and all variables are highly significant. Monarchies and Nordic countries are more trusting while post-communist and more religious countries are less so. The results thus confirm the main findings in the most recent 
studies in the field (Berggren and Bjørnskov, 2011; Robbins, 2012). Although the full sample covers an additional 15 least developed countries, results in the appendix show that the results in columns 1 and 3 are remarkably similar.

With respect to the main variable, we find that both net and market income inequality are negatively related to trust, yet the point estimate of market inequality is significant and substantially larger than the insignificant estimate of net inequality. At first sight, market inequality therefore seems to be the relevant aspect of inequality.

The results across the even-numbered columns provide support for a Kuznets curve in the full sample (in the appendix). ${ }^{25}$ Excluding the poorest countries as in Table 1, the traditional Kuznets curve nonetheless has a consistently negative slope, reflecting that the bulk of the sample is middle-income and rich countries. The political Kuznets curve, conversely, receives substantial support in either sample. Furthermore, the results show consistently lower net and market inequality in post-communist countries. We also find expected evidence of lower net inequality in the Nordic welfare states and less redistribution in common law countries as well as substantial religious differences. Finally, the evidence points to a skills premium (captured by IQ) as suggested in recent studies, which is nevertheless only weakly significant for net inequality and insignificant for market inequality.

In the 89-country sample for which we are likely to observe systematic differences between market and net inequality, we find evidence of two-way causality between trust and inequality only for market inequality. ${ }^{26}$ Examining the size of the feedback from trust to equality with the size of the feed back in the opposite direction provides a sense of the relative importance of mechanisms. If we test the long-run effects of some shock that provokes a one-standard deviation increase in social trust (13.5 percentage points), it eventually turns into a 14.5 point

25 In the full sample with net inequality, the top point of the Kuznets curve top occurs at a GDP level of 4587 USD per capita; with market income, the top point is at 8443 USD. We also find ample evidence of a political Kuznets curve as in Chong (2004) with a top point at a Polity score of approximately 2.5-3 across columns 2 and 4 in both tables.

26 The results in the full sample in the appendix however point to a two-way causality between income inequality and social trust. 
increase in trust due to the feedback from market income inequality. In the long run, market inequality drops by 3.7 points (50\% of a standard deviation). Conversely, a one standard deviation shock to market income inequality (7.6 points) in turn becomes an increase of 8.2 points through feedback effects from trust and induces a drop in trust of 2.3 percentage points (17\% of a standard deviation). Hence, it seems rather clear that the mechanism from trust to inequality is substantially stronger than the feedback in the opposite direction.

As such, the evidence mainly speaks against the standard interpretation of the trustinequality association. In particular, we find no evidence that welfare state redistribution increases trust, as net inequality does not affect trust. ${ }^{27} \mathrm{We}$ therefore devote the next section to testing the robustness of these findings and probing into whether we can identify likely transmission channels suggested in the existing literature.

\section{Robustness tests and potential transmission mechanisms}

In the following, we explore the robustness of the findings to a number of potential other variables and factors, some of which are likely to proxy for specific, potential transmission mechanisms. In Table 3, we first test the findings when including three measures of government size: government full expenditures, including all transfers and subsidies, government final consumption expenditures, which exclude transfers and subsidies, and transfers and subsidies as percent of GDP. These variables subsume the most obvious transmission mechanisms as they provide direct measures of the extent of redistributive policy across countries.

Table 3. Results with welfare state channels

\begin{tabular}{lcccc}
\hline & Trust & Net inequality & Trust & Market inequality \\
& 1 & 2 & 3 & 4 \\
\hline Net inequality & -.045 & & & \\
& $(.183)$ & & $-.264^{*}$ & $(.137)$ \\
Market inequality & & & & $-.239^{* * *}$ \\
Social trust & & $-.113^{* *}$ & $(.072)$
\end{tabular}

\footnotetext{
${ }^{27}$ We have verified that our results are not due to the special status of the Nordic countries. All findings remain unchanged if we take out these five countries of the sample.
} 


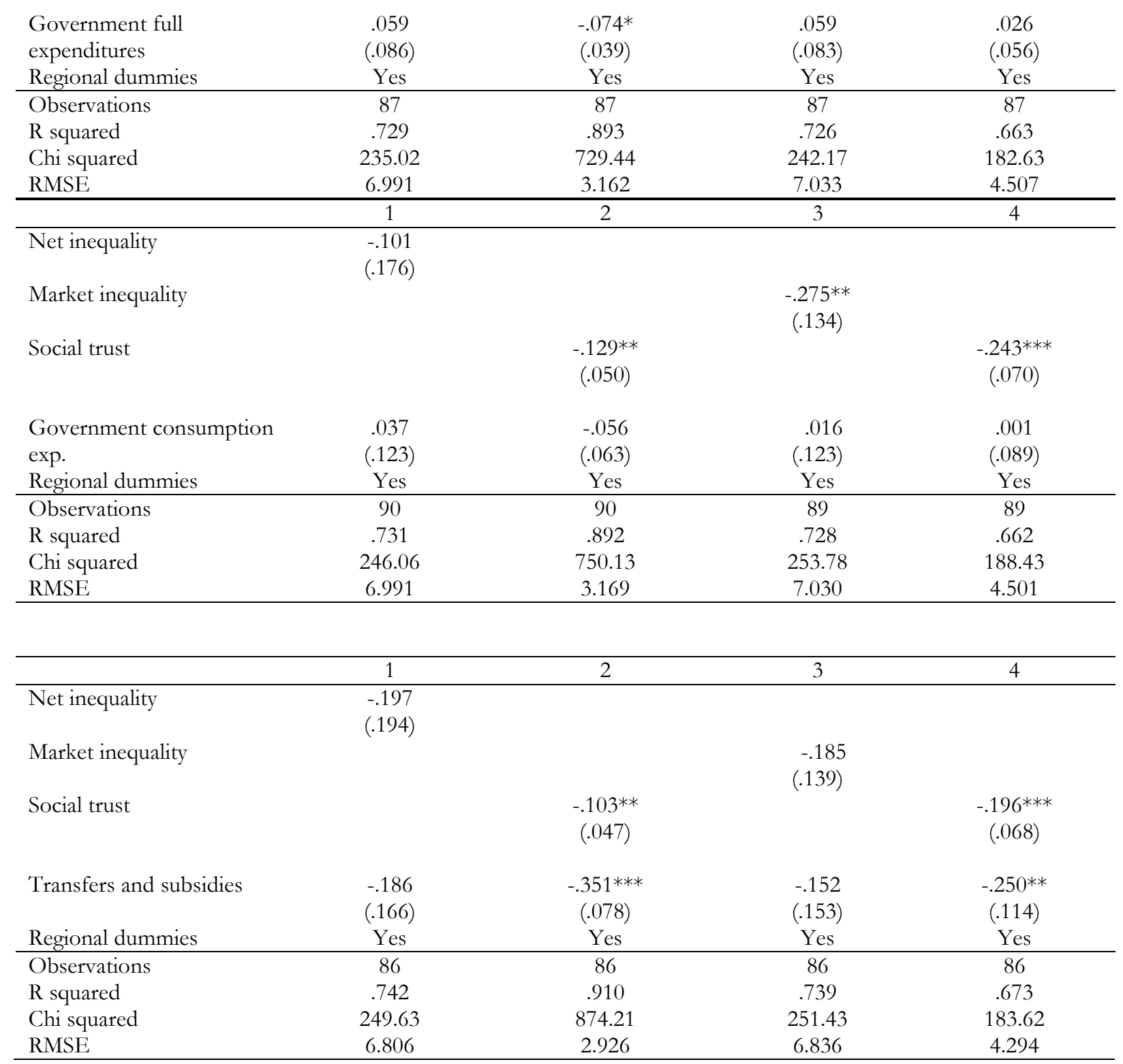

Note: ${ }^{* *}(* *)[*]$ denote significance at $\mathrm{p}<.01(\mathrm{p}<.05)[\mathrm{p}<.10]$; regional dummies control for Asia, Latin America and the Caribbean, North Africa and the Middle East, and Sub-Saharan Africa. The results only include countries with a GDP per capita above 2000 USD in American 2005 dollars.

The table therefore tests for direct effects of welfare states and redistributive efforts that all other things being equal will be associated with larger government sectors. We find an expected negative effect of full expenditures on net inequality, as these expenditures include all redistributive transfers, but no effect on market inequality, and hence no likely effect on social trust. Government final consumption expenditures that include all publicly provided goods and services are never significant while we find that transfers and subsidies reduce both measures of 
inequality. Yet, the effect is substantially larger for net inequality and the inclusion does not change the point estimates of inequality in the trust specification. We thus find no evidence for direct effects of welfare state spending on trust, nor do our results indicate an indirect effect through redistribution.

A set of further results that primarily test the robustness of our main findings are reported in the appendix. Table A3 first tests for the robustness to two characteristics often associated with both trust and inequality: ethnic diversity, which is likely to weaken the support for redistribution, and corruption (measured as absence of corruption) that may arguably reduce the effectiveness of redistribution and could also benefit elite rent-grabbing, which would tend to increase market inequality. ${ }^{28}$ While we find only insignificant support for the effects of ethnic diversity and some indication of effects on corruption - although insignificant, the difference between the point estimates is significant - we note that their inclusion does not change the main results.

Table A4 instead provides evidence for the robustness to including measures of political instability and openness. We find that politically less stable countries tend to have significantly larger net inequality, yet the main difference is that the estimate is insignificant for market inequality. On the other hand, trade openness significantly increases market inequality, but does not affect net inequality. ${ }^{29}$ Again, our main results remain unchanged.

Table A5 tests for two other factors potentially associated with inequality and trust: the relative size of the urban population and population density. We find that countries with larger urban populations have relatively less equal income distributions although the association is only weakly significant for market inequality. However, consistent with cost explanations of redistributive efforts, we also find that more densely populated countries have more market inequality but not more net inequality.

\footnotetext{
${ }^{28}$ Glaeser (2006), Rothstein and Uslaner (2005).

29 The lack of effect from trade openness on net inequality is consistent with Dreher and Gaston (2008).
} 
Finally, Table A6 provides a particularly strong test of the relevance of our results by excluding all poor and lower middle-income countries. In the table, we only retain countries with a PPP-adjusted level of GDP per capita above 7000 USD. In other words, all 55 countries included are clearly economically able to pursue substantive redistributive policies. We note that while the association between trust and net inequality becomes insignificant in both directions - in larger samples, the causal direction from trust to net inequality remains significant - and the effect of market inequality on trust likewise losses significant, the association from trust to market inequality continues to be significant at conventional levels.

Although a sample of only 55 relatively similar countries may not offer enough variation to identify effects with relatively imprecise data, one result remains significant throughout all robustness tests: that social trust lowers market inequality. As such, we must conclude that a set of careful estimates in general provides support for a non-standard interpretation of the trustinequality association. We therefore proceed to discuss these results at some length.

\section{DISCUSSION AND CONCLUSIONS}

In a survey of the trust literature, Nannestad hypothesized that high levels of trust in some countries enable these countries to "solve the collective action dilemma created by their welfare systems" and that as a consequence, "generalized trust is what makes the universal welfare system sustainable and allows equality to coexist with wealth" (Nannestad 2008:430).

Our findings support the ideas of Nannestad as well as Rothstein's idea of the universal welfare state as a social dilemma: social trust aids countries in creating and maintaining welfare states, and larger welfare states do lead to lower net inequality. But this lower net inequality does not feed back into higher levels of trust. Another way of phrasing our results is that it is possible to decrease inequality by expanding the welfare state, but expanding the welfare state is not likely to increase trust. 
We also find that social trust has a direct impact on inequality, regardless of whether or not one controls for the size of the welfare state or direct measures of rent-seeking such as the incidence of corruption. This impact occurs for pre-tax, pre-transfer (market) inequality as well as for post-redistribution (net) inequality. Exploring the opposite causal direction, we find evidence that market inequality affects social trust while we see no support for the claim that net inequality has any causal effect on trust.

The findings that social trust seems to have a direct impact on inequality - even when controlling for the size of the welfare state - while there is no evidence for feedback effects from net inequality, have important implications. For example, they imply that income equality may be correlated with a number of desirable outcomes, but that the correlation is not necessarily causal but can rather be caused by the omitted variable trust. Among the documented positive effects of trust we find better governance, more education, higher economic growth and higher levels of subjective wellbeing. ${ }^{30}$ In addition, Rostila (2007) shows that contexts with low trust, such as the post-socialist context, are more detrimental for the health of distrustful individuals. In overall terms, these findings suggest that contextual social trust could explain health differences between European welfare regimes.

The findings also have implications for the likelihood that policy can affect trust levels. One of the most robust results in the trust literature is the association between social trust and measures of inequality. ${ }^{31}$ Most studies have - explicitly or implicitly - interpreted this association as evidence of an effect of large income differences on social trust. When including policy implications, studies have gone one step further and interpreted the assertion as evidence of the social effectiveness of redistributive welfare state policies. ${ }^{32}$ Nevertheless, the causality of the association has gone more or less untested. Yet, taking care in outlining the causal directions

\footnotetext{
${ }^{30}$ See for example Bjørnskov (2010), Boix and Posner (1998), Helliwell and Huang (2011), Knack and Keefer (1997), Papagapitos and Riley (2009), Putnam (1993) and Zak and Knack (2001).

${ }^{31}$ Bjørnskov (2007), Bjørnskov (2008), Delhey and Newton (2005), Knack and Keefer (1997), Nannestad (2008), Uslaner (2002).

${ }^{32}$ An example here is Rothstein and Uslaner (2005).
} 
between inequality and social trust, we note that if redistributive welfare policy is likely to affect trust, we ought to observe that it is mainly net inequality that is associated with trust, and that causality would run from inequality to trust. As our evidence points to the opposite result, it implies that direct redistribution is not likely to be effective in influencing social trust in any particular direction. In addition, our results show that while the causality is likely to be bidirectional, the effect from trust to inequality is substantially stronger than that from inequality to trust.

As such, our findings do not fit what has emerged as the dominant interpretation of the inequality-trust association in the trust literature. Instead, we find strong support for an effect that allows high-trust countries to have more equal pre-transfer, pre-tax income distributions than found in other comparable societies. Our results thus do not support the policy advice that trust can be increased through redistributive welfare state policies, but rather point to trust as a deeper determinant of formal-institutional and societal characteristics. Put differently, trust appears as an institutional feature belonging to Williamson's (2000) first level of social analysis, the social embeddedness level, where a culturally stable set of norms, traditions and basic beliefs are located, instead of being a policy variable as argued by Jackman and Miller (1998).

The formal theoretical work in section 2 provides some input to a discussion of which types of mechanisms explain the influence of social trust on market inequality, although more work is needed, both theoretically and empirically. Most of the trust literature stresses that social trust reduces the incidence of various forms of rent-seeking, from more inclusion of voter interests to better bureaucratic quality. ${ }^{33}$ One suspect must therefore be some form of rentseeking such as elite rent-grabbing or similar activities that increase elite shares of the income distribution, but are historically limited in high-trust countries. While we leave the specific mechanisms for future research, we stress that such mechanisms are more relevant than the simple policy advice focused on in the literature so far.

\footnotetext{
${ }^{33}$ Bjørnskov (2010), Boix and Posner (1998), Knack (2002), Putnam (1993), Uslaner (2002).
} 
Appendix

Insert Table $A 1$ about here

Insert Table A2 about here

Insert Table $A 3$ about here

Insert Table A4 about here 


\section{References}

Alesina, A., Devleeschauwer, A., Easterly, W., Kurlat, S., and Wacziarg, R. (2003). Fractionalization. Journal of Economic Growth, 8, 155-194.

Anderson, L.R., Mellor, J.M., and Milyo, J. (2006). Induced heterogeneity in trust experiments. Experimental Economics, 9, 223-235.

Arrow, K. (1972). Gifts and exchanges. Philosophy and Public Affairs, 1, 343-367.

Barr, N. (2004). The Economics of the Welfare State. Stanford, California: Stanford University Press.

Berg, J., Dickhaut, J., and McCabe, K. (1995). Trust, Reciprocity, and Social History. Games and Economic Behavior, 10, 122-142.

Berggren, N., and Bjørnskov, C. (2011). Is the Importance of Religion in Daily Life Related to Social Trust? Cross-Country and Cross-State Comparisons. Journal of Economic Behavior \& Organization, 80, 459-480.

Bergh, A., and Bjørnskov, C. (2011). Historical trust levels predict the current size of the welfare state. Kyklos, 64, 1-19.

Binmore, K. (1994). Game Theory and the Social Contract Volume I: Playing Fair. Cambridge, Massachusetts: MIT Press.

Binmore, K., and Samuelson, L. (1994). An economist's perspective on the evolution of norms. Journal of Institutional and Theoretical Economics, 150, 45-71.

Bjørnskov, C. (2007). Determinants of Generalized Trust. A Cross-Country Comparison. Public Choice, 130, 1-21.

Bjørnskov, C. (2008). Social Trust and Fractionalization: A Possible Reinterpretation. European Sociological Review, 24, 271-283.

Bjørnskov, C. (2010). How does Social Trust lead to Better Governance? An Attempt to Separate Electoral and Bureaucratic Mechanisms. Public Choice 144, 323-346.

Bjørnskov,C. and G.T. Svendsen. (in press). Does Social Trust Determine the Size of the Welfare State? Evidence Using Historical Identification. Forthcoming in Public Choice. 
Boix, C., and Posner, D.N. (1998). Social Capital: Explaining its Origins and Effects on Government Performance. British Journal of Political Science, 28, 686-95.

Brülhart, M. and Usunier, J-C. (2012). Does the trust game measure trust? Economics Letters, 115, $20-23$.

Buchanan, J.M. (1975). The Samaritan's Dilemma. In E.S. Phelps (ed.) Altruism, Morality, and Economic Theory, 71-85. Russell Sage Foundation, New York.

CIA. (2010). The CLA World Factbook 2010. Central Intelligence Agency, Washington, DC.

Ciriolo, E. (2007). Inequity aversion and trustees' reciprocity in the trust game. European Journal of Political Economy, 23, 1007-1024.

Coate, S. (1995). Altruism, the Samaritan's Dilemma, and Government Transfer Policy. American Economic Review, 85 (1), 46-57.

Chong, A. (2004). Inequality, democracy, and persistence: is there a political Kuznets curve? Economics and Politics, 16, 189-212.

Cox, J.C., Ostrom,, E., Walker, J.M., Castillo, A.J., Coleman, E., Holahan, R., Schoon, M., and Steed, B. (2009). Trust in private and common property experiments. Southern Economic Journal, 75, 957-975.

Dahl, R. A. (1971). Polyarchy: Participation and Opposition. New Haven: Yale University Press.

Delhey, J., and Newton, K. (2005). Predicting Cross-National Levels of Social Trust: Global Pattern or Nordic Exceptionalism? European Sociological Review, 21, 311-327.

Deininger, K., and Squire, L. (1996). A New Data Set Measuring Income Inequality. World Bank Economic Review, 10, 565-569.

Dreher, A., and Gaston, N. (2008). Has Globalization Increased Inequality? Review of International Economics, 16, 516-536.

Fong, C.M., Bowles, S. and H. Gintis. (2006). Reciprocity, Self-interest and the Welfare State. In S. Kolm and J.M. Ythier (eds.) Handbook on the Economics of Giving, Reciprocity and Altruism. North Holland - Elsevier, Amsterdam. 
Gallup. (2009). Gallup World Poll. Online database available at http://www.gallup.com/consulting/worldpoll/24046/About.aspx.

Gauthier, D. (1987). Morals by Agreement. Oxford: Oxford University Press.

Glaeser, E.L. (2006). Inequality. In B.R. Weingast and D.A. Wittman (eds.), The Oxford Handbook of Political Economy, pp. 624-641. Oxford: Oxford University Press.

Greiner, B., Ockenfels, A., and Werner, P. (2012). The dynamic interplay of inequality and trustAn experimental study. Journal of Economic Behavior and Organization, 81, 355-365.

Gustavsson, M., and Jordahl, H. (2008). Inequality and trust in Sweden: Some inequalities are more harmful than others. Journal of Public Economics, 92, 348-365.

Gwartney, J., Hall, J. and Lawson, R. (2010). Economic Freedom of the World: 2010 Report. Vancouver: the Fraser Institute.

Haile, D., Sadrieh, A., Verbon, H.A.A. (2008). Self-serving dictators and economic growth. Journal of Economic Behavior and Organization, 67, 573-586.

Harsanyi, J.C. (1955). Cardinal Welfare, Individual Ethics and Interpersonal Comparisons of Utility. Journal of Political Economy, 63, 309-320.

Helliwell, J.F., and Wang, S. (2011). Trust and Wellbeing. International Journal of Wellbeing, 1, 42-78.

Hennig-Schmidt, H. (2002). The Impact of Fairness on Decision Making - an Analysis of Different Video Experiments. In F. Andersson, and H. Holm (Eds.), Experimental Economics: Financial Markets, Auctions, and Decision Making. 185-210. USA: Kluwer Academic Publishers.

Heston, A., Summers, R., and Aten, B. (2009). Penn World Tables Mark 6.3. Philadelphia, PA: Center for International Comparisons of Production, Income and Prices, University of Pennsylvania.

Holm, H.J., and Danielson, A. (2005). Tropic Trust Versus Nordic Trust: Experimental Evidence From Tanzania And Sweden. The Economic Journal, 115, 505-532. 
Jackman, R.W., and Miller, R.A. (1998). Social Capital and Politics. Annual Review of Political Science, $1,47-72$.

Johnson, G.E. (1997). Changes in Earnings Inequality: The Role of Demand Shifts. Journal of Economic Perspectives, 11, 41-54.

Jordahl, H. (2008). Economic Inequality. In G.T. Svendsen, and G.L.H. Svendsen (Eds.), Handbook of Social Capital. Cheltenham: Edward Elgar.

Kalai, E. (1977). Nonsymmetric Nash solutions and replications of 2-person bargaining. International Journal of Game Theory, 6, 129-133.

Kalai, E., and Smorodinsky, M. (1975). Other Solutions to Nash's Bargaining Problem. Eco, 43, $513--518$.

Knack, S. and Keefer, P. (1997). Does Social Capital Have an Economic Pay-Off? A CrossCountry Investigation. Quarterly Journal of Economics, 112, 1251-1288

Kumlin, S., and Rothstein, B. (2005). Making and Breaking Social Capital: The Impact of Welfare-State Institutions. Comparative Political Studies, 38, 339-365.

Kuznets, S. (1955). Economic Growth and Income Inequality. American Economic Review, 45, 1-28.

La Porta, R., Lopez-de-Silanes, F., Shleifer, A., and Vishny, R.W. (1997). Trust in large organizations. American Economic Review, 87, 333-338.

Lemieux, T. (2006). Postsecondary Education and Increasing Wage Inequality. American Economic Review Papers and Proceedings, 96, 195-199.

Lindbeck, A. (1995) Welfare State Disincentives with Endogenous Habits and Norms. Scandinavian Journal of Economics, 97 (4), 477-94.

Marshall, M.G., and Marshall, D.R. (2009). Coup D'Etat Events, 1946-2008. Codebook and data available at http://www.systemicpeace.org/inscr/inscr.htm (accessed May 2010).

Naef, M. and Schupp, J. (2009). Measuring Trust: Experiments and Surveys in Contrast and Combination. SOEP working paper 167, DIW Berlin. 
Nash, J. (1950). Equilibrium points in n-person games. Proceedings of the National Academy of Sciences, $36,48-49$.

Nannestad, P. (2008). What Have We Learned About Generalized Trust, If Anything? Annual Review of Political Science, 11, 413-437.

Papagapitos, A., and Riley, R. (2009). Social Trust and Human Capital Formation. Economics Letters, 102, 158-160.

Piccione, M., and Rubinstein, A. (2007). Equilibrium in the Jungle. The Economic Journal, 117, 883896.

Putnam, R. (1993). Making Democracy Work. Civic Traditions in Modern Italy. Princeton, NJ, Princeton University Press.

Rawls, J. (1971). A Theory of Justice. Massachusetts: Harvard University Press.

Robbins, B.G. (2012). Institutional Quality and Generalized Trust: A Nonrecursive Causal Model. Social Indicators Research, 107, 235-258.

Roemer, J.E. (1996). Theories of Distributive Justice. USA: Harvard University Press.

Rostila, M. (2007). Social capital and health in European welfare regimes: a multilevel approach. Journal of European Social Policy, 17, 223-239.

Rothstein, B. (2001). The Universal Welfare State as a Social Dilemma. Rationality and Society, 13:2, 213-233.

Rothstein, B., and Uslaner, E.M. (2005). All for All: Equality, Corruption, and Social Trust. World Politics, 58, 41-72.

Sadrieh, A., and Verbon, H.A.A. (2006). Inequality, cooperation, and growth: an experimental study. European Economic Review, 50, 1197-1222.

Sapienza, P. Toldra, A., and Zingales, L. (2007). Understanding Trust. NBER Working Paper no. 13387.

Schelling, T. (1960). The Strategy of Conflict. USA: Harvard University Press.

Skyrms, B. (1996). Evolution of the Social Contract. Cambridge: Cambridge University Press. 
Solt, F. (2009). Standardizing the World Income Inequality Database. Social Science Quarterly, 9, 231-242.Stigler, G. (1970). Director's Law of Public Income Redistribution. Journal of Political Economy, 13, 1-10.

Svendsen, G.T., and Svendsen, G.L.H. (2008). Handbook of Social Capital. Cheltenham: Edward Elgar.

Sønderskov, K.M. (2011). Explaining large-N cooperation: Generalized social trust and the social exchange heuristic. Rationality and Society, 23, 51-74.

Transparency International. (2010). Transparency International Corruption Perceptions Index 2010. Press Release, Berlin, October.

Uslaner, E.M. (2002). The Moral Foundations of Trust. Cambridge (UK): Cambridge University Press.

Uslaner, E.M. (2008). Where You Stand Depends on Where Your Grandparents Sat: The Inheritability of Generalized Trust. Public Opinion Quarterly, 72, 725-740.

Uslaner, E.M. (In press). Measuring Generalized Trust: In defense of the "Standard" Question. Forthcoming in F. Lyon, G. Möllering, M. Sanders and T. Hatzakis (Eds.), Handbook of Research Methods on Trust. London: Edward Elgar.

Williamson, O.E. (2000). The New Institutional Economics: Taking Stock, Looking Ahead. Journal of Economic Literature, 38, 595-613.

World Bank. (2010). World Development Indicators. Online database, the World Bank: Washington DC.

World Values Survey. (2010). Online database, available at http://www.worldvaluessurvey.org.

Zak, P.J., and Knack, S. (2001). Trust and Growth. The Economic Journal, 111, 295-321.

Zhang, L., Wang, H., Wang, L., and Hsiao, W. (2006). Social Capital and Farmer's Willingness-toJoin a Newly Established Community-Based Health Insurance in Rural China. Health Policy, 76, 233-242. 
Table A1. Descriptive statistics

\begin{tabular}{|c|c|c|c|c|c|}
\hline Variable & Mean & $\begin{array}{l}\text { Standard } \\
\text { deviation }\end{array}$ & Minimum & Maximum & Observations \\
\hline $\begin{array}{l}\text { Absence of } \\
\text { corruption }\end{array}$ & 4.54 & 2.18 & 1.9 & 9.4 & 115 \\
\hline Catholic & 30.27 & 36.56 & 0 & 98 & 116 \\
\hline Common law & 0.25 & 0.43 & 0 & 1 & 116 \\
\hline Coup intensity & 2.63 & 3.74 & 0 & 16 & 116 \\
\hline Democracy & 5.71 & 5.14 & -10 & 10 & 116 \\
\hline Eastern religion & 5.78 & 19.73 & 0 & 95.1 & 116 \\
\hline Ethnic diversity & .39 & .24 & .00 & .93 & 116 \\
\hline $\begin{array}{l}\text { Government } \\
\text { consumption exp. }\end{array}$ & 22.11 & 9.33 & 5.36 & 57.63 & 114 \\
\hline $\begin{array}{l}\text { Government full } \\
\text { expenditures }\end{array}$ & 31.06 & 11.09 & .05 & 68.37 & 110 \\
\hline Market inequality & 44.31 & 7.64 & 27.18 & 66.93 & 105 \\
\hline Intelligence quotient & 88.37 & 10.66 & 63 & 107 & 116 \\
\hline Log GDP per capita & 8.76 & 1.12 & 6.24 & 10.78 & 114 \\
\hline Monarchy & 0.16 & 0.37 & 0 & 1 & 116 \\
\hline Muslim & 19.47 & 31.78 & 0 & 100 & 116 \\
\hline Net inequality & 37.66 & 9.39 & 22.77 & 66.63 & 105 \\
\hline Nordic country & 0.04 & 0.20 & 0 & 1 & 116 \\
\hline Orthodox & 11.77 & 27.05 & 0 & 98 & 116 \\
\hline Population density & 235.96 & 815.19 & 1.53 & 6396.35 & 116 \\
\hline Postcommunist & 0.216 & 0.41 & 0 & 1 & 116 \\
\hline Protestant & 15.02 & 23.78 & 0 & 95 & 116 \\
\hline Religiosity & 0.68 & 0.25 & 0.16 & 1.00 & 114 \\
\hline Social trust & 25.48 & 13.46 & 3.40 & 68.08 & 116 \\
\hline Trade volume & 78.83 & 47.37 & 18.24 & 337.85 & 114 \\
\hline $\begin{array}{l}\text { Transfers and } \\
\text { subsidies }\end{array}$ & 10.62 & 7.26 & .30 & 28.76 & 103 \\
\hline Urban population & 59.43 & 22.47 & 11.37 & 100 & 116 \\
\hline
\end{tabular}


Table A2. Main results, full sample

\begin{tabular}{|c|c|c|c|c|}
\hline & $\begin{array}{c}\text { Trust } \\
1\end{array}$ & $\begin{array}{l}\text { Net inequality } \\
2\end{array}$ & $\begin{array}{c}\text { Trust } \\
3\end{array}$ & $\begin{array}{l}\text { Market inequality } \\
4\end{array}$ \\
\hline Monarchy & $\begin{array}{l}7.069 * * * \\
(2.498)\end{array}$ & & $\begin{array}{l}6.693 * * * \\
(2.467)\end{array}$ & \\
\hline Religiosity & $\begin{array}{c}-18.077 * * * \\
(4.558)\end{array}$ & & $\begin{array}{c}-19.984 * * * \\
(4.467)\end{array}$ & \\
\hline Postcommunist & $\begin{array}{c}-10.162^{* * *} \\
(2.384)\end{array}$ & $\begin{array}{l}-7.451 * * * \\
(2.100)\end{array}$ & $\begin{array}{c}-12.439 * * * \\
(2.486)\end{array}$ & $\begin{array}{l}-8.653 * * * \\
(2.546)\end{array}$ \\
\hline Nordic country & $\begin{array}{c}17.342^{* * *} \\
(4.038)\end{array}$ & $\begin{array}{c}-6.867 * * \\
(3.139)\end{array}$ & $\begin{array}{c}18.807 * * * \\
(3.944)\end{array}$ & $\begin{array}{l}-.266 \\
(3.810)\end{array}$ \\
\hline Log GDP per capita & & $\begin{array}{c}53.029 * * * \\
(9.488)\end{array}$ & & $\begin{array}{l}29.781 * * * \\
(11.458)\end{array}$ \\
\hline Log GDP squared & & $\begin{array}{c}-3.145^{* * *} \\
(.561)\end{array}$ & & $\begin{array}{c}-1.647 * * * \\
(.677)\end{array}$ \\
\hline Democracy & & $\begin{array}{l}.365^{* *} \\
(.151)\end{array}$ & & $\begin{array}{l}.355^{*} \\
(.183)\end{array}$ \\
\hline Democracy squared & & $\begin{array}{c}-.073 * * * \\
(.025)\end{array}$ & & $\begin{array}{c}-.061^{* *} \\
(.030)\end{array}$ \\
\hline Common law & & $\begin{array}{c}1.056 \\
(1.273)\end{array}$ & & $\begin{array}{c}-.912 \\
(1.538)\end{array}$ \\
\hline Orthodox & & $\begin{array}{l}-.008 \\
(.024)\end{array}$ & & $\begin{array}{l}-.047 \\
(.029)\end{array}$ \\
\hline Catholic & & $\begin{array}{c}-.034 \\
(.022)\end{array}$ & & $\begin{array}{l}-.049 * \\
(.027)\end{array}$ \\
\hline Protestant & & $\begin{array}{l}.049 \\
(.035)\end{array}$ & & $\begin{array}{l}.048 \\
(.042)\end{array}$ \\
\hline Muslim & & $\begin{array}{c}-.079 * * * \\
(.026)\end{array}$ & & $\begin{array}{c}-.113^{* * *} \\
(.032)\end{array}$ \\
\hline Eastern religion & & $\begin{array}{l}-.023 \\
(.034)\end{array}$ & & $\begin{array}{l}-.062 \\
(.041)\end{array}$ \\
\hline Intelligence quotient & & $\begin{array}{l}.272^{* *} \\
(.108)\end{array}$ & & $\begin{array}{c}.178 \\
(.131)\end{array}$ \\
\hline Net inequality & $\begin{array}{c}-.257^{*} \\
(.144)\end{array}$ & & & \\
\hline Market inequality & & & $\begin{array}{c}-.339 * * * \\
(.119)\end{array}$ & \\
\hline Social trust & & $\begin{array}{c}-.136 * * \\
(.053)\end{array}$ & & $\begin{array}{c}-.218^{* * * *} \\
(.064)\end{array}$ \\
\hline Regional dummies & Yes & Yes & Yes & Yes \\
\hline Observations & 104 & 104 & 104 & 104 \\
\hline R squared & .676 & .805 & .674 & .559 \\
\hline Chi squared & 221.56 & 438.55 & 229.84 & 146.04 \\
\hline RMSE & 7.601 & 4.074 & 7.622 & 5.010 \\
\hline
\end{tabular}

Note: $* * *(* *)[*]$ denote significance at $\mathrm{p}<.01(\mathrm{p}<.05)[\mathrm{p}<.10]$; regional dummies control for Asia, Latin America and the Caribbean, North Africa and the Middle East, and Sub-Saharan Africa. 
Table A3: Robustness, excluding the poorest countries

\begin{tabular}{|c|c|c|c|c|}
\hline & $\begin{array}{c}\text { Trust } \\
1 \\
\end{array}$ & $\begin{array}{c}\text { Inequality } \\
2 \\
\end{array}$ & $\begin{array}{c}\text { Trust } \\
3 \\
\end{array}$ & $\begin{array}{c}\text { Inequality } \\
4 \\
\end{array}$ \\
\hline Net inequality & $\begin{array}{l}-.117 \\
(.177)\end{array}$ & & & \\
\hline Market inequality & & & $\begin{array}{c}-.258^{*} \\
(.134)\end{array}$ & \\
\hline Social trust & & $\begin{array}{c}-.138^{* * * *} \\
(.051)\end{array}$ & & $\begin{array}{c}-.240 * * * \\
(.070)\end{array}$ \\
\hline Ethnic diversity & $\begin{array}{c}4.681 \\
(4.195)\end{array}$ & $\begin{array}{c}2.829 \\
(2.050)\end{array}$ & $\begin{array}{c}3.712 \\
(4.208)\end{array}$ & $\begin{array}{l}-1.708 \\
(2.884)\end{array}$ \\
\hline Regional dummies & Yes & Yes & Yes & Yes \\
\hline Observations & 89 & 89 & 89 & 89 \\
\hline $\mathrm{R}$ squared & .733 & .893 & .729 & .663 \\
\hline Chi squared & 246.99 & 749.93 & 253.66 & 187.18 \\
\hline RMSE & 6.984 & 3.174 & 7.026 & 4.514 \\
\hline & 1 & 2 & 3 & 4 \\
\hline Net inequality & $\begin{array}{l}-.132 \\
(.176)\end{array}$ & & & \\
\hline Market inequality & & & $\begin{array}{c}-.301 * * \\
(.133)\end{array}$ & \\
\hline Social trust & & $\begin{array}{c}-.186 * * * \\
(.052)\end{array}$ & & $\begin{array}{c}-.312^{* * *} \\
(.067)\end{array}$ \\
\hline Absence of corruption & & $\begin{array}{l}-.123 \\
(.420)\end{array}$ & & $\begin{array}{c}.842 \\
(.538)\end{array}$ \\
\hline Regional dummies & Yes & Yes & Yes & Yes \\
\hline Observations & 90 & 90 & 90 & 90 \\
\hline $\mathrm{R}$ squared & .729 & .865 & .726 & .638 \\
\hline Chi squared & 246.44 & 583.42 & 255.36 & 173.71 \\
\hline RMSE & 7.003 & 3.546 & 7.053 & 4.653 \\
\hline
\end{tabular}

Note: ${ }^{* * *}(* *)[*]$ denote significance at $\mathrm{p}<.01(\mathrm{p}<.05)[\mathrm{p}<.10]$; regional dummies control for Asia, Latin America and the Caribbean, North Africa and the Middle East, and Sub-Saharan Africa. The results only include countries with a GDP per capita above 2000 USD in American 2005 dollars. 
Table A4: Robustness, excluding the poorest countries

\begin{tabular}{|c|c|c|c|c|}
\hline & $\begin{array}{c}\text { Trust } \\
1\end{array}$ & $\begin{array}{c}\text { Inequality } \\
2 \\
\end{array}$ & $\begin{array}{c}\text { Trust } \\
3 \\
\end{array}$ & $\begin{array}{c}\text { Inequality } \\
4 \\
\end{array}$ \\
\hline Net inequality & $\begin{array}{l}-.129 \\
(.176)\end{array}$ & & & \\
\hline Market inequality & & & $\begin{array}{c}-.293 * * \\
(.133)\end{array}$ & \\
\hline Social trust & & $\begin{array}{c}-.189 * * * \\
(.051)\end{array}$ & & $\begin{array}{c}-.301 * * * \\
(.067)\end{array}$ \\
\hline Coup intensity & & $\begin{array}{l}.319^{* *} \\
(.141)\end{array}$ & & $\begin{array}{c}.299 \\
(.186)\end{array}$ \\
\hline Regional dummies & Yes & Yes & Yes & Yes \\
\hline Observations & 90 & 90 & 90 & 90 \\
\hline $\mathrm{R}$ squared & .730 & .872 & .727 & .641 \\
\hline Chi squared & 246.42 & 620.92 & 254.68 & 174.18 \\
\hline RMSE & 7.001 & 3.451 & 7.046 & 4.639 \\
\hline & 1 & 2 & 3 & 4 \\
\hline Net inequality & $\begin{array}{l}-.139 \\
(.176)\end{array}$ & & & \\
\hline Market inequality & & & $\begin{array}{c}-.304 * * \\
(.133)\end{array}$ & \\
\hline Social trust & & $\begin{array}{c}-.188^{* * * *} \\
(.052)\end{array}$ & & $\begin{array}{c}-.298 * * * \\
(.066)\end{array}$ \\
\hline Trade volume & & $\begin{array}{c}.009 \\
(.009)\end{array}$ & & $\begin{array}{l}.029 * * \\
(.012)\end{array}$ \\
\hline Regional dummies & Yes & Yes & Yes & Yes \\
\hline Observations & 90 & 90 & 90 & 90 \\
\hline $\mathrm{R}$ squared & .729 & .866 & .726 & .649 \\
\hline Chi squared & 246.65 & 588.46 & 255.86 & 182.85 \\
\hline RMSE & 7.005 & 3.535 & 7.055 & 4.580 \\
\hline
\end{tabular}

Note: ${ }^{* *}\left({ }^{* *}\right)\left[{ }^{*}\right]$ denote significance at $\mathrm{p}<.01(\mathrm{p}<.05)[\mathrm{p}<.10]$; regional dummies control for Asia, Latin America and the Caribbean, North Africa and the Middle East, and Sub-Saharan Africa. The results only include countries with a GDP per capita above 2000 USD in American 2005 dollars. 
Table A5: Robustness, excluding the poorest countries

\begin{tabular}{|c|c|c|c|c|}
\hline & $\begin{array}{c}\text { Trust } \\
1 \\
\end{array}$ & $\begin{array}{c}\text { Inequality } \\
2 \\
\end{array}$ & $\begin{array}{c}\text { Trust } \\
3 \\
\end{array}$ & $\begin{array}{c}\text { Inequality } \\
4 \\
\end{array}$ \\
\hline Net inequality & $\begin{array}{l}-159 \\
(.175)\end{array}$ & & & \\
\hline Market inequality & & & $\begin{array}{c}-.313^{* *} \\
(.133)\end{array}$ & \\
\hline Social trust & & $\begin{array}{c}-.189 * * * \\
(.051)\end{array}$ & & $\begin{array}{c}-.301 * * * \\
(.067)\end{array}$ \\
\hline Urban population & & $\begin{array}{l}.069 * * \\
(.034)\end{array}$ & & $\begin{array}{l}.083^{*} \\
(.044)\end{array}$ \\
\hline Regional dummies & Yes & Yes & Yes & Yes \\
\hline Observations & 90 & 90 & 90 & 90 \\
\hline $\mathrm{R}$ squared & .729 & .870 & .725 & .639 \\
\hline Chi squared & 247.41 & 612.13 & 256.55 & 176.70 \\
\hline RMSE & 7.012 & 3.481 & 7.064 & 4.645 \\
\hline & 1 & 2 & 3 & 4 \\
\hline Net inequality & $\begin{array}{l}-.111 \\
(.176)\end{array}$ & & & \\
\hline Market inequality & & & $\begin{array}{c}-.275^{* *} \\
(.133)\end{array}$ & \\
\hline Social trust & & $\begin{array}{c}-.128 * * \\
(.051)\end{array}$ & & $\begin{array}{c}-.201 * * * \\
(.065)\end{array}$ \\
\hline Population density & & $\begin{array}{c}.001 \\
(.001)\end{array}$ & & $\begin{array}{c}.003^{* * *} \\
(.001)\end{array}$ \\
\hline Regional dummies & Yes & Yes & Yes & Yes \\
\hline Observations & 90 & 90 & 90 & 90 \\
\hline $\mathrm{R}$ squared & .730 & .892 & .728 & .713 \\
\hline Chi squared & 246.06 & 748.74 & 254.39 & 238.89 \\
\hline RMSE & 6.997 & 3.174 & 7.032 & 4.145 \\
\hline
\end{tabular}

Note: ${ }^{* * *}(* *)[*]$ denote significance at $\mathrm{p}<.01(\mathrm{p}<.05)[\mathrm{p}<.10]$; regional dummies control for Asia, Latin America and the Caribbean, North Africa and the Middle East, and Sub-Saharan Africa. The results only include countries with a GDP per capita above 2000 USD in American 2005 dollars. 
Table A6: Robustness, only rich and newly developed countries

\begin{tabular}{lcccc}
\hline & Trust & Inequality & Trust & Inequality \\
& 1 & 2 & 3 & 4 \\
\hline Net inequality & .056 & & & \\
Market inequality & $.218)$ & & -.114 & \\
Social trust & & & $(.158)$ & $-.262^{* *}$ \\
& & -.055 & & $(.108)$ \\
Regional dummies & & $.071)$ & & Yes \\
\hline Observations & Yes & Yes & Yes & 55 \\
R squared & 55 & 55 & 55 & .517 \\
Chi squared & .786 & .870 & .781 & 5.012 \\
RMSE & 203.44 & 370.95 & 203.56 & 63.75 \\
\hline
\end{tabular}

Note: $* * *(* *)[*]$ denote significance at $\mathrm{p}<.01(\mathrm{p}<.05)[\mathrm{p}<.10]$; regional dummies control for Asia, Latin America and the Caribbean, North Africa and the Middle East, and Sub-Saharan Africa. The results only include countries with a GDP per capita above 7000 USD in American 2005 dollars. 